\title{
Serum Bilirubin in the Czech Population - Relationship to the Risk of Myocardial Infarction in Males -
}

\author{
Lenka Eremiasova, MD; Jaroslav A Hubacek, PhD; Vilém Danzig, MD, PhD; \\ Věra Adamkova, MD, PhD; Lenka Mrazova, PhD; Jan Pitha, MD, PhD; \\ Věra Lanska, MD, PhD; Renata Cífková, MD, PhD; Libor Vitek, MD, PhD
}

\begin{abstract}
Background: The potential antiatherogenic role of bilirubin is generally acknowledged, so the aim of this study was to determine serum bilirubin concentrations and the prevalence of Gilbert syndrome (GS) in the Czech general population with particular reference to its relationship to the risk of myocardial infarction (MI).

Methods and Results: Biochemical markers were analyzed in 2 independent Czech post-MONICA studies (in total, $\mathrm{n}=3,311$ ), and in 741 male MI patients. The UGT1A1 promoter gene variant (rs81753472) was analyzed in these MI patients and in the first control population cohort $(n=717)$. Medians of serum bilirubin concentrations in the 2 Czech general population cohorts were 9.6 and $9.8 \mu \mathrm{mol} / \mathrm{L}(10.7$ and $11.3 \mu \mathrm{mol} / \mathrm{L}$ in males, and 8.3 and $8.8 \mu \mathrm{mol} / \mathrm{L}$ in females; $\mathrm{P}<0.01)$. The prevalence of $\mathrm{GS}$ was $8.9 \%$, twice as high in males compared with females (11.6 vs. $6.1 \% ; \mathrm{P}<0.01)$. The UGT1A1 (TA) 7/7 promoter repeats significantly influenced serum bilirubin concentrations in the controls, but not in the MI patients. Serum bilirubin concentrations were significantly lower in Ml patients (7.7 vs. $10.7 \mu \mathrm{mol} / \mathrm{L} ; \mathrm{P}<0.01$ ), with almost 5 -fold lower prevalence of GS.
\end{abstract}

Conclusions: Serum bilirubin concentrations and the prevalence of GS were determined in the Czech general population. Significantly lower serum bilirubin concentrations were observed in male MI patients.

Key Words: Bilirubin; Cardiovascular diseases; Gilbert syndrome; Myocardial infarction; UGT1A1 promoter gene variants

D espite admirable progress in prevention and treatment, cardiovascular diseases (CVD) remain the most common cause of mortality and morbidity in developed countries. ${ }^{1}$

In addition to the conventional cardiovascular risk factors, such as dyslipidemia, smoking, diabetes mellitus, hypertension and obesity, increased oxidative stress with impaired defense mechanisms has been recognized as an important factor contributing to the pathogenesis of CVD. ${ }^{2}$ Among the natural endogenous antioxidants, bilirubin, a catabolic product of heme degradation in the intravascular compartment, is acknowledged as one of the most potent. ${ }^{3}$ Bilirubin is also a potent anti-inflammatory, ${ }^{4}$ or even a signaling molecule. ${ }^{5}$

Originally, bilirubin was considered only a nonfunctional product of heme catabolism. Although its antioxi- dant activities had been described a long time ago, its role as a natural antioxidant was convincingly re-discovered in 1987. ${ }^{6}$ Since then, bilirubin has been intensively discussed as a factor with potentially protective effects, mainly against cardiovascular ${ }^{7}$ and cancer diseases, ${ }^{8}$ particularly in males.

Similar to all other conventional cardiovascular risk factors, genetics play an important role in the systemic bilirubin concentration, but the number of participating genes seems to be rather low., ${ }^{910}$ Among the environmental/nongenetic factors affecting serum/plasma bilirubin concentrations, sex, ethnicity, smoking and several dietary habits are of importance. ${ }^{11}$

Within heme degradation and bilirubin production, bilirubin UDP-glucuronosyl transferase 1 (UGT1A1), an enzyme responsible for bilirubin glucuronosylation in the liver tissue, plays a crucial role. In humans, this enzyme is

Received March 15, 2020; revised manuscript received June 16, 2020; accepted June 22, 2020; J-STAGE Advance Publication released online August 26, 2020 Time for primary review: 36 days

Institute of Medical Biochemistry and Laboratory Diagnostics, Faculty General Hospital and 1st Faculty of Medicine (L.E., L.V.), 2nd Department of Internal Medicine, Faculty General Hospital and 1st Faculty of Medicine (L.E., V.D., R.C.), Center for Cardiovascular Prevention, 1st Faculty of Medicine and Thomayer Hospital (R.C.), 4th Department of Internal Medicine, 1st Faculty of Medicine Faculty and General Hospital (L.V.), Charles University, Praha; Center for Experimental Medicine (J.A.H., L.M., J.P.), Department of Preventive Cardiology (V.A.), Medical Statistics Unit (V.L.), Institute for Clinical and Experimental Medicine, Praha, Czech Republic

The first two authors contributed equally to this work (L.E., J.A.H.).

Mailing address: Libor Vítek, MD, PhD, Institute of Medical Biochemistry and Laboratory Diagnostics, 1st Faculty of Medicine, Charles University, Na Bojišti 3, Praha 2, 12000, Czech Republic. E-mail: vitek@cesnet.cz

All rights are reserved to the Japanese Circulation Society. For permissions, please e-mail: cj@j-circ.or.jp

ISSN-1346-9843 


\begin{tabular}{|c|c|c|c|c|}
\hline & $\begin{array}{c}\text { Cohort A } \\
(n=717)\end{array}$ & $\begin{array}{l}\text { Cohort B } \\
(n=2,594)\end{array}$ & $\begin{array}{c}\text { Cohort A } \\
\text { Males }(n=442)\end{array}$ & $\begin{array}{c}\text { MI cohort } \\
\text { Males }(n=741)\end{array}$ \\
\hline $\mathrm{M} / \mathrm{F}$ ratio & 1.61 & 0.91 & - & - \\
\hline Age (years) & $48.4 \pm 11$ & $48 \pm 11$ & $49 \pm 11$ & $54.7 \pm 8^{*}$ \\
\hline $\mathrm{BMI}\left(\mathrm{kg} / \mathrm{m}^{2}\right)$ & $28.1 \pm 4.8$ & $28.3 \pm 5.5$ & $28.4 \pm 3.9$ & $28.8 \pm 4.5$ \\
\hline LDL cholesterol (mmol/L) & $3.54 \pm 1.2$ & $3.16 \pm 0.9$ & $3.64 \pm 1$ & $3.57 \pm 1.1$ \\
\hline HDL cholesterol (mmol/L) & $1.31 \pm 0.4$ & $1.49 \pm 0.4$ & $1.22 \pm 0.4$ & $1.16 \pm 0.3^{*}$ \\
\hline Triacylglycerols (mmol/L) & $1.77 \pm 1.1$ & $1.34 \pm 1.0$ & $2.01 \pm 1.2$ & $1.85 \pm 1.7^{\star}$ \\
\hline Smoking (\%) & 48.8 & 43.8 & 58.5 & $83.2^{*}$ \\
\hline Arterial hypertension (\%) & 41.7 & 40.1 & 47.1 & 49.9 \\
\hline Diabetes mellitus (\%) & 4.5 & 6.4 & 5 & $17.9^{*}$ \\
\hline
\end{tabular}

Data shown as mean $\pm \mathrm{SD}$. ${ }^{*} \mathrm{P}<0.01$, compared with control cohort $\mathrm{A}$ male population.

coded by the UGT1A1 gene (OMIM No. 191740). Based on genome-wide association studies, ${ }^{12}$ UGT1A1 is 1 of the major genetic determinants of systemic bilirubin concentrations. ${ }^{910}$ The expression of UGT1A1 is significantly influenced by functional (TA) repeat polymorphism (rs81753472) located within the ATATAA element in the gene promoter region. The longer allele (TA) 7 (known as the UGT1A $1 * 28$ allele) is associated with lower gene expression, resulting, as a consequence, in increased systemic bilirubin concentrations. Bilirubin concentrations in (TA) $7 / 7$ homozygotes, in particular in Caucasians, are significantly higher in comparison with individuals carrying at least 1 (TA)6 allele. ${ }^{13}$

Increased serum bilirubin concentrations have been associated with reduced risk of CVD in both retrospective, as well as prospective clinical studies (for reviews see references 7,8 ), although not all of them confirmed this association. ${ }^{14}$ Physiological serum/plasma bilirubin concentrations have a wide range of $2-17 \mu \mathrm{mol} / \mathrm{L}(0.1-1 \mathrm{mg} / \mathrm{dL})$, with substantial differences related to ethnicity, sex, age and other factors. ${ }^{11,15}$ Because of the importance of bilirubin and the genes modulating its systemic concentrations, physiological concentrations should be defined more precisely, separately for men and women. ${ }^{15}$ It is known that individuals with serum bilirubin concentrations $<7 \mu \mathrm{mol} / \mathrm{L}$ have increased cardiovascular risk by $30 \%$ compared with those with bilirubin concentrations $>10 \mu \mathrm{mol} / \mathrm{L} .{ }^{16}$ Based on these data, a significant improvement in the prediction of cardiovascular risk has been reported when bilirubin is included in the cardiovascular risk calculation algorithm. ${ }^{17}$

Surprisingly, data on serum/plasma bilirubin concentrations in general populations from Central Europe are missing, which complicates proposals for novel cardiovascular risk algorithms.

The aim of our study was thus to (1) assess the serum bilirubin concentrations in the Czech general population, (2) examine the prevalence of elevated liver function test (LFTs), important confounders of serum bilirubin concentrations and also predictors of cardiovascular morbidity, (3) examine the association of serum bilirubin concentrations with UGT1A1 promoter gene polymorphisms, and (4) assess these factors as possible risk factors of acute myocardial infarction (MI) in Czech males.

\section{Methods}

\section{Study Populations}

General Population The Czech general population in this study consisted of 2 cohorts. The first cohort (cohort A) was a retrospective consecutive subset $(n=717,62 \%$ of males, aged 26-64 years) of the Czech post-MONICA population first examined in 1997-1998 and re-examined in 2000-2001 with serum bilirubin concentrations analyzed and selected genes affecting bilirubin metabolism investigated. The samples of biological material were frozen at $-80^{\circ} \mathrm{C}$ immediately after blood collection until later analysis for the purpose of this study.

The second, larger cohort of the Czech general population was used to confirm the bilirubin concentration data obtained from the first cohort. This second population subset (cohort B) was derived from the prospective Czech post-MONICA study conducted between 2015 and 2018 and consisted of 2,594 individuals randomly selected from the Czech general population (48\% males, aged 25-64 years).

The protocols of the Czech post-MONICA studies were approved by the Ethics Committee of the Institute for Clinical and Experimental Medicine and Thomayer Hospital, Prague, Czech Republic (No. G 14-08-04). All participants provided informed consent.

\section{Patients}

A total of 741 consecutive adult male patients who had suffered their first MI before age 65 (MI cohort) and were hospitalized in the Coronary Care Unit (CCU) of the Institute for Clinical and Experimental Medicine between April 2006 and April 201418,19 were included in this analysis. Blood samples collected within $24 \mathrm{~h}$ after admission to the CCU were analyzed for biochemical parameters.

All examined patients were self-reported Caucasians and voluntarily signed written informed consent to participate in the study. The study protocol was also in agreement with the Helsinki Declaration and approved by the institutional ethics committee.

\section{Risk Factors and Laboratory Analysis}

Traditional atherogenic risk factors were defined as described in detail previously. ${ }^{18-20}$

Fasting serum concentrations of lipids (total cholesterol, high-density lipoprotein (HDL) cholesterol and triacylglyceroles) were analyzed using conventional enzymatic methods (reagents from Boehringer Mannheim Diagnostics and Hoffmann-La Roche) and bilirubin as well as LFT activities were determined by automatic analyzer (UniCel DxC 800 Synchron Clinical Systems, Beckman Coulter, UK) using routine clinical chemistry methods. The upper limit of physiological bilirubin concentration was set as 


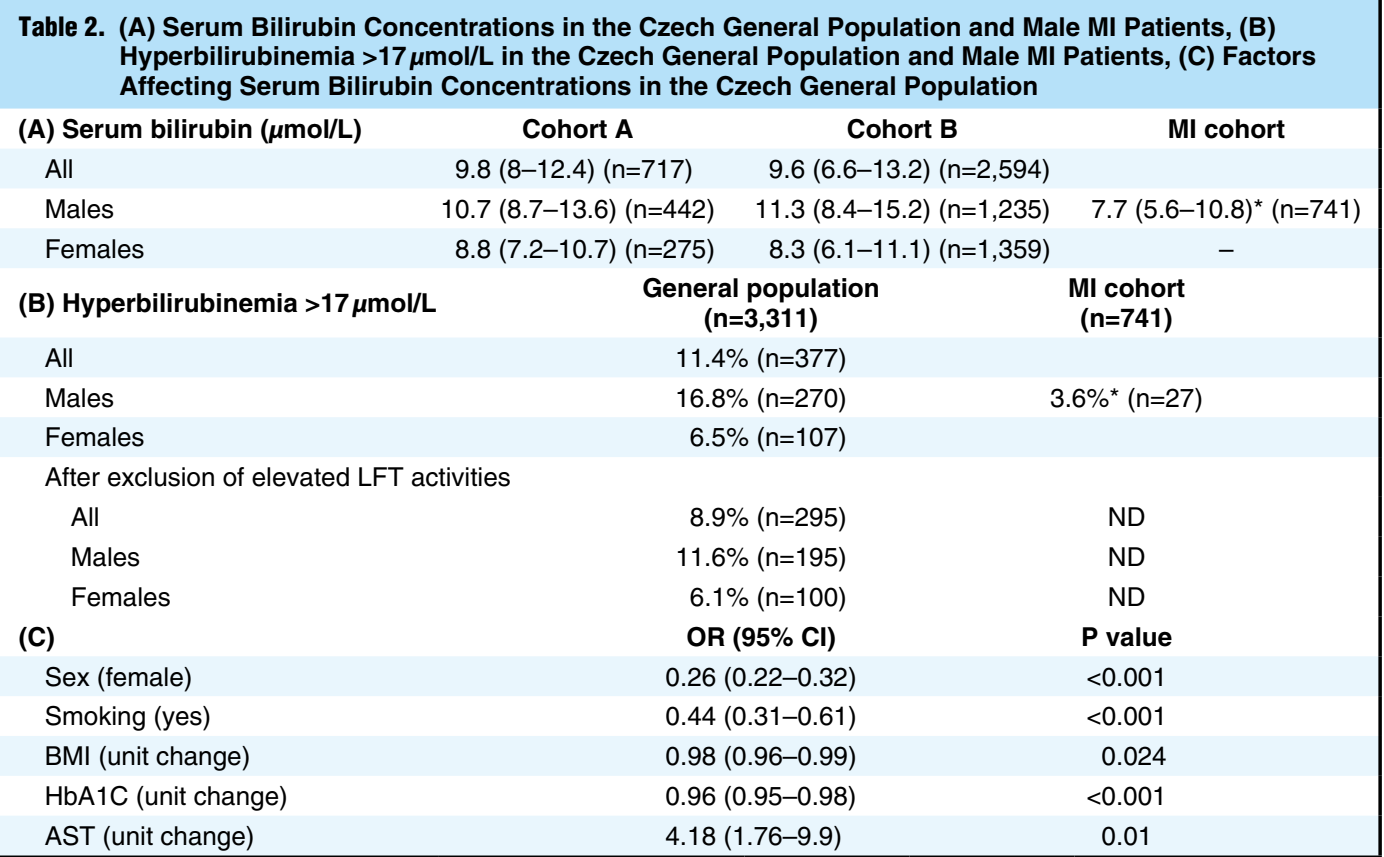

(A) Data shown as median and interquartile range. ${ }^{*} \mathrm{P}<0.01$, compared with both control populations. (B) Concentrations expressed as median and interquartile range. ${ }^{*} \mathrm{P}<0.01$, compared with the general population. (C) OR represents the odds of having a serum bilirubin concentration above the median of the total general population $(9.6 \mu \mathrm{mol} / \mathrm{L}$, cohort B). AST, aspartate aminotransferase; BMI, body mass index; Cl, confidence interval; HbA1C, glycated hemoglobin; LFT, liver function test; MI, myocardial infarction; ND, not determined due to elevation of myocardial enzyme activities confounding the liver enzyme profile; OR, odds ratio.

$17 \mu \mathrm{mol} / \mathrm{L}$. The following values of LFTs were considered abnormal: aspartate aminotransferase (AST) $>0.72 \mu \mathrm{kat} / \mathrm{L}$, alanine aminotransferase (ALT) $>0.78 \mu \mathrm{kat} / \mathrm{L}$, and $\gamma$-glutamyltransferase (GGT) $>0.84 \mu \mathrm{kat} / \mathrm{L}$.

The general characteristics of the all the examined study populations are given in Table 1.

\section{DNA Analysis}

DNA was isolated from the whole EDTA blood sample using a slightly modified method of Miller et al. ${ }^{21}$ UGT1 A1 gene promoter variants were analyzed by multicolored capillary electrophoresis as described previously. ${ }^{22,23}$

\section{Statistical Analysis}

Data are expressed as mean \pm SD or median and interquartile range depending on the distribution. The differences in studied variables were assessed by the Student's t-test or Mann-Whitney rank test (continuous variables), chi-square test or Fisher's exact test (for categorical variables). The association between serum bilirubin concentration and UGT1 A1 promoter genotype was tested using the KruskalWallis test with Dunn's post hoc analysis. Linear and logistic regression analyses were used to assess the dependence of the variables. SigmaPlot 11.0 (Systat Software, Inc., CA, USA) was used for statistical analyses. All analyses were performed with the significance level set to 0.05 .

HW equilibrium (www.dr-petrek.eu/documents/HWE. xls) Chi square (http://www.physics.csbsju.edu/cgi-bin/ stats/contingency_form.sh?nrow $=2 \&$ ncolumn $=3$ ) was calculated using the freely available www tool. For categorical variables, chi-square test or Fisher's exact test was used.

\section{Results}

\section{Serum Bilirubin Concentrations in the Czech General Population}

The medians of serum bilirubin concentration in the Czech general population, based on our 2 cohort studies consisting of $>3,300$ subjects, were 9.6 and $9.8 \mu \mathrm{mol} / \mathrm{L}$, respectively (Table 2A). Substantially higher serum bilirubin concentrations were found in both cohorts of males compared with females $(10.7$ and 11.3 vs. 8.3 and $8.8 \mu \mathrm{mol} / \mathrm{L}$, $\mathrm{P}<0.01$ ) (Table 2A). The $95 \%$ reference interval for the whole population (defined as representing the $95 \%$ limits for the distribution of the values of the analyte measured in the reference population ${ }^{24}$ ), based on the larger cohort $\mathrm{B}$, was $4.3-23.6 \mu \mathrm{mol} / \mathrm{L}$; the same reference interval was 5.5-27.5 $\mu \mathrm{mol} / \mathrm{L}$ for males, and 3.8-19.9 $\mu \mathrm{mol} / \mathrm{L}$ for females.

Prevalence of Gilbert syndrome (GS: defined as unconjugated hyperbilirubinemia $>17 \mu \mathrm{mol} / \mathrm{L}$ with no signs of hemolysis or overt liver disease; normal LFTs were used as a surrogate marker) in our cohorts representing the Czech general population was $8.9 \%(11.6 \%$ in males, and $6.1 \%$ in females, $\mathbf{P}<0.01)$ (Table 2B). Serum bilirubin concentrations were significantly affected by sex, smoking, body mass index (BMI), glycated hemoglobin (HbA1C) and AST, but not by age, ALT and GGT activities, or total, low-density lipoprotein (LDL) and HDL cholesterol concentrations (Table 2C). Females had the odds of having serum bilirubin concentrations above the median of the whole population lowered by $74 \%$, while the same odds were lower in smokers by $56 \%$ (smoking was associated with a $12 \%$ decrease in serum bilirubin concentrations, from $9.9(7.3-13.4)$ to 8.7 $(6.2-11.7 \mu \mathrm{mol} / \mathrm{L}, \mathrm{P}<0.001)$. Each single point increase of BMI was associated with a $2 \%$ decrease, and each $1 \%$ 
Table 3. Serum Bilirubin Concentrations According to Smoking Status

\begin{tabular}{lccc} 
& \multicolumn{2}{c}{ Bilirubin $(\boldsymbol{\mu}$ mol/L) } & P value \\
Cohort A & Smokers $(n=350)$ & Nonsmokers $(n=367)$ & \\
Cohort B & $9.7(7.7-12.1)$ & $10.1(8.2-12.9)$ & 0.03 \\
& Smokers $(n=1,138)$ & Nonsmokers $(n=1,448)$ & \\
Cohort A males & $9.2(6.6-12.7)$ & $9.9(7.3-13.4)$ & 0.0001 \\
& Smokers $(n=259)$ & Nonsmokers $(n=183)$ & \\
Ml cohort & $10(8.1-12.6)$ & $11.5(9.5-14.6)$ & 0.001 \\
& Smokers $(n=617)$ & Nonsmokers $(n=115)$ & \\
& $7.8(5.7-10.8)$ & $7.9(5.4-10.9)$ & NS
\end{tabular}

Data shown as median and interquartile range. Ex-smokers not included in the analysis. NS, not significant.

\begin{tabular}{|c|c|c|c|c|c|c|c|c|c|c|c|c|c|c|c|}
\hline \multirow{2}{*}{$\begin{array}{l}\text { (A) UGT1A1 } \\
\text { genotype }\end{array}$} & \multicolumn{4}{|c|}{ Cohort A $(n=717)$} & \multicolumn{3}{|c|}{ Cohort A males $(n=442)$} & \multicolumn{4}{|c|}{ Cohort A females $(n=275)$} & \multicolumn{4}{|c|}{ MI cohort $(n=741)$} \\
\hline & & $\mathrm{n}$ & & $\begin{array}{l}\text { ilirubin } \\
\text { umol/L) }\end{array}$ & $\mathbf{n}$ & & $\begin{array}{l}\text { lirubin } \\
\text { mol/L) }\end{array}$ & & $\mathbf{n}$ & & $\begin{array}{l}\text { ilirubin } \\
\text { umol/L) }\end{array}$ & & $\mathbf{n}$ & & $\begin{array}{l}\text { lirubin } \\
\text { mol/L) }\end{array}$ \\
\hline$(\mathrm{TA})_{6 / 6}$ & & 291 & & $(7.3-11)$ & $177^{+}(40 \%)$ & $9.9(8$ & $8.1-11.8)$ & & $4^{+}(41.5 \%)$ & 8.1( & $(6.5-9.3)$ & & $9(44.3 \%)$ & $7.3(5$. & $5.3-10.1)^{*}$ \\
\hline$(\mathrm{TA})_{6 / 7}$ & & 327 & $9.9(8$ & $(8.3-12.1)$ & $201(45.5 \%)$ & $10.8(8$ & $8.9-12.9)$ & & $6(45.8 \%)$ & 9.1( & $(7.4-10.6)$ & & $5(42.5 \%)$ & $8.4(6$. & $0.4-11.2)^{*}$ \\
\hline$(\mathrm{TA})_{7 / 7}$ & & 99 & $14.8(1$ & (11.2-18.3) & $64(14.5 \%)$ & $16.2(1$ & 12.4-19.7) & & $5^{++}(12.7 \%)$ & 11.8( & $(9.8-15.6)$ & & $7(13.1 \%)$ & $7.2(5-$ & $5-11.1)^{\star}$ \\
\hline$P$ for trend & \multicolumn{4}{|c|}{0.001} & \multicolumn{3}{|c|}{0.001} & \multicolumn{3}{|c|}{0.001} & $(\mathrm{n}=275)$ & \multicolumn{4}{|c|}{ NS } \\
\hline \multirow{2}{*}{$\begin{array}{l}\text { (B) UGT1A1 } \\
\text { genotype }\end{array}$} & & Smokers & & nsmokers & Smokers & Non: & nsmokers & & mokers & & nsmokers & & mokers & Nons & nsmokers \\
\hline & $\mathrm{n}$ & $\begin{array}{l}\text { Bilirubin } \\
(\mu \mathrm{mol} / \mathrm{L})\end{array}$ & $\mathrm{n}$ & $\begin{array}{l}\text { Bilirubin } \\
(\mu \mathrm{mol} / \mathrm{L})\end{array}$ & $n \begin{array}{r}\text { Bilirubin } \\
(\mu \mathrm{mol} / \mathrm{L})\end{array}$ & $\mathrm{n}$ & $\begin{array}{l}\text { Bilirubin } \\
(\mu \mathrm{mol} / \mathrm{L})\end{array}$ & $\mathbf{n}$ & $\begin{array}{l}\text { Bilirubin } \\
(\mu \mathrm{mol} / \mathrm{L})\end{array}$ & $\mathbf{n}$ & $\begin{array}{l}\text { Bilirubin } \\
(\mu \mathrm{mol} / \mathrm{L})\end{array}$ & n & $\begin{array}{l}\text { Bilirubin } \\
(\mu \mathrm{mol} / \mathrm{L})\end{array}$ & n & $\begin{array}{l}\text { Bilirubin } \\
(\mu \mathrm{mol} / \mathrm{L})\end{array}$ \\
\hline$(\mathrm{TA})_{6 / 6}$ & 140 & $\begin{array}{c}8.7 \\
(7.0-10.9)\end{array}$ & 149 & $\begin{array}{c}9.2 \\
(7.8-11.3)\end{array}$ & $101 \begin{array}{c}9.5 \\
(7.3-11.3)\end{array}$ & 75 & $\begin{array}{c}10.6 \\
(8.9-13.6)\end{array}$ & 39 & $\begin{array}{c}7.7 \\
(6.1-9.3)\end{array}$ & 74 & $\begin{array}{c}8.2 \\
(6.8-9.4)\end{array}$ & 273 & $\begin{array}{c}7.4 \\
(5.3-10)\end{array}$ & 51 & $\begin{array}{c}6.9 \\
(5.1-10.6)\end{array}$ \\
\hline$(\mathrm{TA})_{6 / 7}$ & 161 & $\begin{array}{c}9.7 \\
(8.0-12.0)\end{array}$ & 167 & $\begin{array}{c}10.2 \\
(8.4-2.4)\end{array}$ & $122 \begin{array}{c}10.1 \\
(8.5-12.5)\end{array}$ & 80 & $\begin{array}{c}11.4 \\
(9.7-13.2)\end{array}$ & 39 & $\begin{array}{c}9 \\
(7.4-10.4)\end{array}$ & 87 & $\begin{array}{c}9.1 \\
(7.8-10.6)\end{array}$ & 259 & $\begin{array}{c}8.5 \\
(6.6-11.3)\end{array}$ & 53 & $\begin{array}{c}8.4 \\
(6.1-11.1)\end{array}$ \\
\hline$(\mathrm{TA})_{7 / 7}$ & & $\begin{array}{c}14.1 \\
(10.4-18.2)\end{array}$ & & $\begin{array}{c}15.3 \\
(11.6-19.4)\end{array}$ & $36 \begin{array}{c}15.3 \\
(10.5-18.4)\end{array}$ & 27 & $\begin{array}{c}17.7 \\
(14.2-24.4)\end{array}$ & 11 & $\begin{array}{c}11.3 \\
(9.5-15.6)\end{array}$ & 22 & $\begin{array}{c}12.5 \\
(8.6-15.5)\end{array}$ & 85 & $\begin{array}{c}9.7 \\
(8-12)\end{array}$ & 11 & $\begin{array}{c}6.8 \\
(4.7-10.9)\end{array}$ \\
\hline$P$ for trend & & 0.001 & & 0.0001 & 0.0001 & & 0.0001 & & 0.01 & & 0.0001 & & 0.01 & & NS \\
\hline
\end{tabular}

(A) Data shown as median and interquartile range. ${ }^{*} \mathrm{P}<0.01$ compared with cohort $A$ males. ${ }^{+}$Includes 1 individual with genotype $(T A)_{5 / 6}$; ++ includes 2 individuals with genotype $(T A)_{7 / 8}$. (B) Data shown as median and interquartile range. NS, not significant.

increase in $\mathrm{HbA} 1 \mathrm{C}$ with a $4 \%$ decrease of the odds of having serum bilirubin concentrations below the median of the bilirubin concentrations of the total study population (Table 2C). Conversely, each elevation in AST activity by $1 \mu \mathrm{kat} / \mathrm{L}$ was associated with a marked increase in serum bilirubin concentrations; thus, AST was most likely a marker of serious deterioration in hepatic function (Table 2C).

Detailed analysis of the role of smoking on serum bilirubin concentrations across all studied populations revealed consistently lower bilirubin levels in smokers in all cohorts representing the Czech general population (Table 3). However, smoking was not associated with lower serum bilirubin concentrations in the male patients suffering from MI (Table 3).

\section{Frequency of the Gene Variants Affecting Serum Bilirubin Concentrations in the Czech General Population}

No significant difference in the frequencies of UGT1A1 genotypes was found between males and females (Table 4A), although serum bilirubin concentrations were significantly higher in males than in females $(10.7$ vs. $8.8 \mu \mathrm{mol} / \mathrm{L} ; \mathrm{P}<0.01$, Table 2A). Within cohort A, representing the Czech general population at large, the $U G T 1 A 1$ promoter gene variants were significantly associated with serum concentrations of bilirubin $(\mathrm{P}<0.01$, Table 4A). The highest serum bilirubin concentration was found in TA7/7 (UGT1A1*28) homozygotes, both male and female (Table 4A).

\section{Serum Bilirubin Concentrations, UGT1A1 Genotypes and Association With MI}

In male patients suffering from acute MI, serum bilirubin concentrations were significantly lower compared with the control male population (7.7 vs. 10.7 and $11.3 \mu \mathrm{mol} / \mathrm{L}$, $\mathrm{P}<0.01$, Table 2A). The distribution of $U G T 1 A 1$ genotypes was fully comparable between these 2 groups (Table 4A).

Although there was a close relationship between $U G T 1 A 1$ promoter gene polymorphism and the serum bilirubin concentrations in the control population, such an association was not detected in the MI patients (Table 4A) and this trend was also present when analyzing serum bilirubin concentrations according to $U G T 1 A 1$ genotype separately according to smoking status (Table 4B).

Prevalence of Elevated LFTs in the Czech General Population Because elevated activity of LFTs (in particular ALT and GGT) is an important predictor of increased overall as well as cardiovascular morbidity and mortality, ${ }^{25,26}$ we were interested in the prevalence rates of elevated LFTs in the 


\begin{tabular}{|c|c|c|c|}
\hline & $\begin{array}{c}\text { All } \\
(n=2,594)\end{array}$ & $\begin{array}{c}\text { Males } \\
(n=1,235)\end{array}$ & $\begin{array}{r}\text { Females } \\
(n=1,359)\end{array}$ \\
\hline ALT & $5.5 \%$ & $9.7 \%$ & $1.8 \%$ \\
\hline AST & $3.2 \%$ & $4.7 \%$ & $1.8 \%$ \\
\hline GGT & $18.4 \%$ & $28.9 \%$ & $8.9 \%$ \\
\hline ALT/AST/GGT & $20.7 \%$ & $32.6 \%$ & $9.7 \%$ \\
\hline
\end{tabular}

The following LFT values were considered abnormal: aspartate aminotransferase (AST) $>0.72 \mu \mathrm{kat} / \mathrm{L}$, alanine aminotransferase (ALT) $>0.78 \mu \mathrm{kat} / \mathrm{L}$, and gamma-glutamyltransferase (GGT) $>0.84 \mu \mathrm{kat} / \mathrm{L}$.

Czech general population. Thus, LFT activities were assessed in the large cohort B representing this population. Elevation of ALT, AST or GGT separately was observed in $3.2-18.4 \%$ of individuals and elevated values of any of these liver enzymes were found in as much as $20.7 \%$ of cohort B individuals (Table 5). Elevation of LFT activities was more than 3-fold greater in males compared with females, with GGT being most often elevated (Table 5).

A significant positive linear relationship was detected between $\mathrm{BMI}$ and GGT $(\mathrm{P}<0.001), \mathrm{HbA1C}(\mathrm{P}<0.001)$, and serum triacylglycerol concentrations $(\mathrm{P}<0.001)$, and a negative association was detected for BMI and HDL cholesterol concentrations $(\mathrm{P}<0.001)$. Similarly, HbA1C closely correlated with ALT, AST and GGT activities $(\mathrm{P}<0.001)$.

\section{Discussion}

The physiological range of systemic bilirubin concentrations is a matter of debate, with many factors affecting this parameter, including, in particular, sex and ethnicity. ${ }^{15}$ Because serum bilirubin concentration has become recognized as an important risk predictor of cardiovascular as well as other diseases, ${ }^{\mathbf{8}}$ it is even more important to establish proper physiological ranges for particular populations. In our study performed in relatively large cohorts of Caucasians randomly selected from the Czech general population, we identified medians of serum bilirubin concentrations to be 9.6 (cohort A) and $9.8 \mu \mathrm{mol} / \mathrm{L}$ (cohort B) for both sexes in total, with higher values observed in men $(10.7-11.3 \mu \mathrm{mol} / \mathrm{L})$ compared with women $(8.3-8.8 \mu \mathrm{mol} / \mathrm{L})$. Notably, our established $95 \%$ reference intervals for serum bilirubin concentrations were much wider and shifted to higher values compared with current reference intervals, with substantial differences between males and females.

The reference intervals for serum bilirubin in the Czech general population are within a range of 5-17 $\mu \mathrm{mol} / \mathrm{L}$ and come from 2 sources, both based on US populations and giving the same values: (1) data from the Massachusetts General Hospital in Boston published in a report by Kratz et al, ${ }^{27}$ and (2) Beckman Coulter reference (unpublished) data for bilirubin determination. This is the usual approach that the majority of clinical chemistry laboratories follow. ${ }^{28}$ Thus, current physiological ranges for serum bilirubin concentrations should be reconsidered, adjusting for individual populations and separately for males and females. ${ }^{15}$ In addition, our study data showed the serum bilirubin concentrations decreasing with increasing BMI, and $\mathrm{HbA} 1 \mathrm{C}$ and in smokers, all factors associated with the risk of atherosclerosis and metabolic syndrome.

The prevalence of GS (defined historically as unconjugated hyperbilirubinemia $>17 \mu \mathrm{mol} / \mathrm{L}$ in the absence of hemolysis or overt liver disease) in the Czech general population was $8.9 \%$ (11.6\% in males and $6.1 \%$ in females).

Serum bilirubin concentrations were much lower in acute MI patients, consistent with prevailing opinion regarding the atheroprotective effects of bilirubin. ${ }^{16,29}$ However, 2 recent meta-analyses showed transient elevation of serum bilirubin concentrations following acute $\mathrm{MI},{ }^{\mathbf{3 0}, 31}$ most likely related to a feedback increase of bilirubin production by stress-induced HMOX1 activity. ${ }^{32}$ Our observation of substantially lower serum bilirubin concentrations in acute MI patients may be due to the fact that the blood samples for the bilirubin analysis were collected in the later phase of acute MI, because the peak of bilirubin elevation is reached within $18-21 \mathrm{~h}$ after heart attack. ${ }^{32}$ Serum bilirubin concentrations also differ according to the severity of coronary atherosclerosis, ${ }^{33,34}$ which may account for our observation as well.

Our results confirmed that the UGT1AI (TA)6/7 repeat polymorphism is an important determinant of serum bilirubin concentrations in the Czech general population, with no significant difference in this gene variant frequency between males and females (Table 5), consistent with data reported previously. ${ }^{35}$ However, the association between UGT1 Al (TA)6/7 repeat polymorphism and serum bilirubin concentrations was not observed in the male MI patients. In addition, the genotype distribution of the $U G T 1 A 1$ repeat polymorphism was almost identical to that in the controls. This somewhat surprising finding might be explained by the incomplete, approximately $50 \%$ penetrance of the UGT1 Al (TA)7/7 promoter gene variant responsible for GS manifestation. ${ }^{9}$ Therefore, it is likely that $U G T 1 A 1$ (TA) $7 / 7$ mutation carriers suffering from MI are those not previously presenting with the mildly elevated serum bilirubin concentrations typical of GS. Thus, the low systemic bilirubin concentrations in the male MI patients seemed to be a consequence of increased oxidative stress associated with atherosclerosis and diabetes present in these MI patients rather than due to genetic predisposition. Overproduction of reactive oxygen species leads to the oxidation of bilirubin to biliverdin, ${ }^{36}$ as well as to a series of tri-, di- and monopyrrolic bilirubin oxidation products, ${ }^{37}$ thus resulting in decreased serum bilirubin concentrations. Interestingly, smoking was not associated with lower serum bilirubin concentrations in this acutely sick cohort, suggesting that clinical factors mentioned earlier are probably more important in bilirubin homeostasis.

In addition, our study has provided data on the prevalence of elevated liver enzymes in the Czech general population. This is also an important finding because elevated activity of GGT is mostly due to underlying non-alcoholic fatty liver disease (NAFLD), ${ }^{38}$ being a strong predictor of cardiovascular morbidity and mortality, ${ }^{39}$ as well as of diabetes $^{\mathbf{4 0}}$ independently of alcohol intake. ${ }^{\mathbf{4 1}}$ A similar positive association with cardiovascular morbidity was also reported for elevated ALT activity, ${ }^{\mathbf{4}}$ another strong marker of NAFLD,${ }^{43}$ positively correlating with multiple metabolic risk factors. ${ }^{44}$

Increased activity of both aminotransferases (ALT, AST) in general populations is quite high, reaching 3-15\% as reported in various epidemiological studies worldwide. ${ }^{43-48}$ The same applies to GGT activity, elevations of which have been reported in $13 \%$ of the general population. ${ }^{46}$ The data from our population study demonstrated substantially higher prevalence of elevated liver enzymes correlating positively with BMI, blood lipids and $\mathrm{HbA1C}$, 
especially in men, underlying the high risk of cardiovascular and metabolic diseases in these individuals.

\section{Study Limitations}

The cross-sectional study design together with the fact that bilirubin was assessed in the acute phase of MI are the limitations of our study. On the other hand, we were able to compare the bilirubin data of these patients with those of a relevant and representative population sample.

In conclusion, we determined serum bilirubin concentrations and the prevalence of GS in the Czech general population, with a high prevalence of increased LFTs. Substantially lower serum bilirubin concentrations, but not specific $U G T 1 A 1$ genotypes, were observed in the male MI patients.

\section{Conflicts of Interest}

The authors report no relationships that could be construed as a conflict of interest.

All authors take responsibility for all aspects of the reliability and freedom from bias of the data presented and their discussed interpretation.

\section{Acknowledgment}

The study was supported by grants No. 15-28895A,15-27109A, IKEM IN 00023001 and RVO-VFN64165/2020 provided by the Ministry of Health of the Czech Republic and by grants PROGRES Q25/LF1 and SVV 260370-2020 provided by Charles University.

\section{IRB Information}

The study was approved by the Ethics Committee of the Institute for Clinical and Experimental Medicine and Thomayer Hospital, Prague, Czech Republic (No. G 14-08-04).

\section{References}

1. Timmis A, Townsend N, Gale CP, Torbica A, Lettino M, Petersen SE, et al. European Society of Cardiology: Cardiovascular Disease Statistics 2019. Eur Heart J 2020; 41: 12-85.

2. Wang Y, Chun OK, Song WO. Plasma and dietary antioxidant status as cardiovascular disease risk factors: A review of human studies. Nutrients 2013; 5: 2969-3004.

3. Gazzin S, Vitek L, Watchko J, Shapiro SM, Tiribelli C. A novel perspective on the biology of bilirubin in health and disease. Trends Mol Med 2016; 22: 758-768.

4. Jangi S, Otterbein L, Robson S. The molecular basis for the immunomodulatory activities of unconjugated bilirubin. Int $J$ Biochem Cell Biol 2013; 45: 2843-2851.

5. Vitek L. Bilirubin as a signaling molecule. Med Res Rev 2020; 40: $1335-1351$.

6. Stocker R, Yamamoto Y, McDonagh AF, Glazer AN, Ames BN. Bilirubin is an antioxidant of possible physiological importance. Science 1987; 235: $1043-1046$.

7. Vitek L. Bilirubin and atherosclerotic diseases. Physiol Res 2017; 66: $\mathrm{S} 11-\mathrm{S} 20$

8. Wagner $\mathrm{KH}$, Wallner M, Molzer C, Gazzin S, Bulmer AC, Tiribelli $\mathrm{C}$, et al. Looking to the horizon: The role of bilirubin in the development and prevention of age-related chronic diseases. Clin Sci (Lond) 2015; 129: 1-25.

9. Bosma PJ, Chowdhury JR, Bakker C, Gantla S, de Boer A, Oostra BA, et al. The genetic basis of the reduced expression of bilirubin UDP-glucuronosyltransferase 1 in Gilbert's syndrome. N Engl J Med 1995; 333: 1171-1175.

10. Lin JP, Vitek L, Schwertner HA. Serum bilirubin and genes controlling bilirubin concentrations as biomarkers for cardiovascular disease. Clin Chem 2010; 56: 1535-1543.

11. Vitek L, Bellarosa C, Tiribelli C. Induction of mild hyperbilirubinemia: Hype or real therapeutic opportunity? Clin Pharmacol Ther 2019; 106: $568-575$.

12. Johnson AD, Kavousi M, Smith AV, Chen MH, Dehghan A, Aspelund T, et al. Genome-wide association meta-analysis for total serum bilirubin levels. Hum Mol Genet 2009; 18: 2700-2710.

13. Beutler E, Gelbart T, Demina A. Racial variability in the UDPglucuronosyltransferase 1 (UGT1A1) promoter: A balanced polymorphism for regulation of bilirubin metabolism? Proc Natl
Acad Sci USA 1998; 95: 8170-8174.

14. Stender S, Frikke-Schmidt R, Nordestgaard BG, Grande P, Tybjaerg-Hansen A. Genetically elevated bilirubin and risk of ischaemic heart disease: Three Mendelian randomization studies and a meta-analysis. J Intern Med 2013; 273: 59-68.

15. Vitek L. Bilirubin as a predictor of diseases of civilization: Is it time to establish decision limits for serum bilirubin concentrations? Arch Biochem Biophys 2019; 672: 108062.

16. Novotny L, Vitek L. Inverse relationship between serum bilirubin and atherosclerosis in men: A meta-analysis of published studies. Exp Biol Med 2003; 228: 568-571.

17. Schwertner HA, Fischer JR Jr. Comparison of various lipid, lipoprotein, and bilirubin combinations as risk factors for predicting coronary artery disease. Atherosclerosis 2000; 150: 381-387.

18. Hubacek JA, Vrablik M, Dlouha D, Stanek V, Gebauerova M, Adamkova V, et al. Gene variants at FTO, 9p21, and 2q36.3 are age-independently associated with myocardial infarction in Czech men. Clin Chim Acta 2016; 454: 119-123.

19. Hubacek JA, Stanek V, Gebauerova M, Pilipcincova A, Dlouha D, Poledne R, et al. A FTO variant and risk of acute coronary syndrome. Clin Chim Acta 2010; 411: 1069-1072.

20. Pitha J, Hubacek JA, Poledne R, Stanek V, Aschermann M, Gebauerova M, et al. Genetic determination of the prognosis in survivors of acute coronary syndromes: Study design and rationale for a multicentric study. Cor Vasa 2007; 49: 134-137.

21. Miller SA, Dykes DD, Polesky HF. A simple salting out procedure for extracting DNA from human nucleated cells. Nucleic Acids Res 1988; 16: 1215.

22. Jiraskova A, Lenicek M, Vitek L. Simultaneous genotyping of microsatellite variations in HMOX1 and UGT1A1 genes using multicolored capillary electrophoresis. Clin Biochem 2010; 43: 697-699.

23. Jiraskova A, Novotny J, Novotny L, Vodicka P, Pardini B, Naccarati A, et al. Association of serum bilirubin and promoter variations in HMOX1 and UGT1A1 genes with sporadic colorectal cancer. Int J Cancer 2012; 131: 1549-1555.

24. Ceriotti F. Prerequisites for use of common reference intervals. Clin Biochem Rev 2007; 28: 115-121.

25. Kunutsor SK, Apekey TA, Khan H. Liver enzymes and risk of cardiovascular disease in the general population: A meta-analysis of prospective cohort studies. Atherosclerosis 2014; 236: 7-17.

26. Kunutsor SK, Apekey TA, Seddoh D, Walley J. Liver enzymes and risk of all-cause mortality in general populations: A systematic review and meta-analysis. Int J Epidemiol 2014; 43: 187-201.

27. Kratz A, Ferraro M, Sluss PM, Lewandrowski KB. Case records of the Massachusetts General Hospital: Weekly clinicopathological exercises: Laboratory reference values. $N$ Engl J Med 2004; 351: 1548-1563.

28. Friedberg RC, Souers R, Wagar EA, Stankovic AK, Valenstein PN, College of American Pathologists. The origin of reference intervals. Arch Pathol Lab Med 2007; 131: 348-357.

29. Schwertner HA, Vitek L. Gilbert syndrome, UGT1A1*28 allele, and cardiovascular disease risk: Possible protective effects and therapeutic applications of bilirubin. Atherosclerosis 2008; 198: $1-11$.

30. Lan Y, Liu H, Liu J, Zhao H, Wang H. Is serum total bilirubin a predictor of prognosis in arteriosclerotic cardiovascular disease?: A meta-analysis. Medicine (Baltimore) 2019; 98: e17544.

31. Shen H, Zeng C, Wu X, Liu S, Chen X. Prognostic value of total bilirubin in patients with acute myocardial infarction: A metaanalysis. Medicine (Baltimore) 2019; 98: e13920.

32. Okuhara K, Kisaka T, Ozono R, Kurisu S, Inoue I, Soga J, et al. Change in bilirubin level following acute myocardial infarction is an index for heme oxygenase activation. South Med J 2010; 103: $876-881$

33. Sahin O, Akpek M, Elcik D, Karadavut S, Simsek V, Tulmac M, et al. Bilirubin levels and the burden of coronary atherosclerosis in patients with STEMI. Angiology 2013; 64: 200-204.

34. Canpolat U, Aytemir K, Yorgun H, Hazirolan T, Kaya EB, Sahiner L, et al. Association of serum total bilirubin levels with the severity, extent and subtypes of coronary atherosclerotic plaques detected by coronary CT angiography. Int J Cardiovasc Imaging 2013; 29: 1371-1379.

35. Liu JY, Qu K, Sferruzza AD, Bender RA. Distribution of the UGT1A1*28 polymorphism in Caucasian and Asian populations in the US: A genomic analysis of 138 healthy individuals. Anticancer Drugs 2007; 18: 693-696.

36. Sedlak TW, Snyder SH. Messenger molecules and cell death: Therapeutic implications. JAMA 2006; 295: 81-89.

37. Jašprova J, Dvorak A, Vecka M, Lenicek M, Lacina O, Valaskova 
$\mathrm{P}$, et al. A novel accurate LC-MS/MS method for quantitative determination of Z-lumirubin. Sci Rep 2020; 10: 4411.

38. Vernon G, Baranova A, Younossi ZM. Systematic review: The epidemiology and natural history of non-alcoholic fatty liver disease and non-alcoholic steatohepatitis in adults. Aliment Pharmacol Ther 2011; 34: 274-285.

39. Ndrepepa G, Kastrati A. Gamma-glutamyl transferase and cardiovascular disease. Ann Transl Med 2016; 4: 481.

40. Kunutsor SK, Abbasi A, Adler AI. Gamma-glutamyl transferase and risk of type II diabetes: An updated systematic review and dose-response meta-analysis. Ann Epidemiol 2014; 24: 809-816.

41. Fraser A, Harris R, Sattar N, Ebrahim S, Smith GD, Lawlor DA. Gamma-glutamyltransferase is associated with incident vascular events independently of alcohol intake: Analysis of the British Women's Heart and Health Study and Meta-Analysis. Arterioscler Thromb Vasc Biol 2007; 27: 2729-2735.

42. Ioannou GN, Weiss NS, Boyko EJ, Mozaffarian D, Lee SP Elevated serum alanine aminotransferase activity and calculated risk of coronary heart disease in the United States. Hepatology 2006; 43: 1145-1151.
43. Ioannou GN, Boyko EJ, Lee SP. The prevalence and predictors of elevated serum aminotransferase activity in the United States in 1999-2002. Am J Gastroenterol 2006; 101: 76-82.

44. Mahady SE, Gale J, Macaskill P, Craig JC, George J. Prevalence of elevated alanine transaminase in Australia and its relationship to metabolic risk factors: A cross-sectional study of 9,447 people. J Gastroenterol Hepatol 2017; 32: 169-176.

45. Lee TH, Kim WR, Benson JT, Therneau TM, Melton LJ III. Serum aminotransferase activity and mortality risk in a United States community. Hepatology 2008; 47: 880-887.

46. Ruhl CE, Everhart JE. Elevated serum alanine aminotransferase and gamma-glutamyltransferase and mortality in the United States population. Gastroenterology 2009; 136: 477-485.e411.

47. Hyun HJ, Shim JJ, Kim JW, Lee JS, Lee CK, Jang JY, et al. The prevalence of elevated alanine transaminase and its possible causes in the general Korean population. J Clin Gastroenterol 2014; 48: 534-539.

48. Clark JM, Brancati FL, Diehl AM. The prevalence and etiology of elevated aminotransferase levels in the United States. Am J Gastroenterol 2003; 98: 960-967. 